\title{
Communication of Elderly-Children and Elderly-Children in Law, Social Support and Successful Aging of Men and Women Elderly
}

\author{
Endang Nursolehah* \\ Department of Family and Consumer \\ Sciences, \\ Faculty of Human Ecology, \\ Bogor Agricultural University
}

*Corresponding author: endangnursolehah5@gmail.com

\author{
Diah Krisnatuti \\ Department of Family and Consumer \\ Sciences, \\ Faculty of Human Ecology, \\ Bogor Agricultural University
}

\begin{abstract}
The success aging of elderly is characterized by the comforting conditions of loving care and attention from family and relatives, health and happy. The aim of this research is to find the difference, correlation and effect of communication with children and children in law and social support to success of life on elderly men and women. This research sample is chosen purposely as many as 60 young elderly aged 60-69 years old which is divided into 30 elderly men and 30 elderly women who still have a partner, children and children in law. The largest proportion of elderly on communication of elderly-children, communication of elderly-children in law, social support and successful in elderly variable are in the medium category. Communication elderly-children and communication elderly-children in law have a significant positive correlation with social support. Social support is related and has a significant positive effect on the success of elderly life, it means that the higher social support will increase the success of elderly life.
\end{abstract}

Keywords : communication, elderly men and women, social support, successful aging

\begin{abstract}
Abstrak
Kesuksesan hidup lansia ditandai dengan kondisi kenyamanan penuh kasih sayang dan perhatian dari keluarga dan kerabat, sehat dan bahagia. Penelitian ini bertujuan untuk mengetahui perbedaan, hubungan dan pengaruh komunikasi lansia dengan anak dan menantu serta dukungan sosial terhadap kesuksesan hidup lansia pria dan wanita. Pengambilan contoh dilakukan secara purposive sebanyak 60 orang lansia awal usia 60 sampai 69 tahun yang dibedakan menjadi 30 lansia pria dan 30 lansia wanita yang masih memiliki pasangan, anak, dan menantu. Proporsi terbesar lansia pada variabel komunikasi lansia-anak, komunikasi lansia-menantu, dukungan sosial dan kesuksesan hidup lansia berada pada kategori sedang. Terdapat hubungan positif sangat signifikan antara komunikasi lansia-anak dengan lansiamenantu, komunikasi lansia-anak dan komunikasi lansia-menantu dengan dukungan sosial. Dukungan sosial berhubungan dan berpengaruh positif signifikan terhadap kesuksesan hidup lansia, artinya semakin tinggi dukungan sosial maka akan meningkatkan kesuksesan hidup lansia.
\end{abstract}

Keywords: komunikasi, lansia pria dan wanita, dukungan sosial, kesuksesan hidup lansia, 


\section{INTRODUCTION}

The 2010 Population Census results show that Indonesians have a life expectancy up to 70.7 years, while the 2014 CBS (Central Bureau Statistic) records the number of elderly people rising from 18.1 million in 2010 to 20.24 million. Increasing the number of elderly will bring the consequences of the emergence of various problems related to elderly life as in terms of health, social, economic, and spiritual. At this advanced stage the task of development and adaptation for the elderly includes the circumstances of job loss, relationships (friends or spouses), and communication.

The successful aging as a description of the feelings of happiness and satisfaction both in the present and the past (Havigurst in Agus 2013). Previous research has found a difference in the successful aging in terms of gender. In this study wanted to know whether there are differences in the success of life and other variables such as family communication and social support and the tendency of higher values are in the elderly men or women.

Sarafino (2006) states that social support refers to the comfort, attention, appreciation, or help that provided by others or groups to people. Rodin and Salovey in Smet (1994) revealed that the most important social support is from the family. According to Olson and Barnes (2004), family communication is an action in making information, ideas, and knowledge perceived by each family member. Communication of parent and child is effective if both parties understand and open each other. The effective communication between parents with the son-in-law is with interpersonal communication that impact on the creation of a harmonious relationship. When parent and children communicate indirectly, they lead to a lack of recognition of each other and uncomfortable feelings (Prentice 2008). The purposes of this study are; (1) analyzing differences in the characteristics of elderly, elderly communication with children, elderly communication with child-in-law, social support and successful living in the elderly men and women; (2) analyzing elderly communication relationship with children, elderly communication with child-in-law, social support with successful aging at elderly men and women; and (3) analyze the influence of elderly communication with children, elderly communication with son-in-law, and social support to the success of life in elderly men and women.

\section{RESEARCH METHOD}

This research use cross-sectional study design because the research done at one time. This research was conducted in three urban villages namely Bubulak Village, West Cilendek Village and Menteng Village, Bogor Barat Sub-District, Bogor City, West Java Province. Determination of the research site was conducted by purposely. Bubulak is one of subdistrict which have the highest number of elderly in West Bogor District (BPS 2015). Time of study includes data retrieval, processing and report writing conducted from February to June 2017.

West Bogor sub-district is the widest sub-district in Bogor city with total population in 2015 as many as 232634 people (BPS 2016) and has the most elderly population in Bogor City with the number of 12094 people aged around 60 to 69 years. There are subdistrict which has the highest number of elderly, that are 912 people of West Cilendek Village, Menteng Village as many as 954 people, and 
Bubulak 892 urban village, so the three urban villages are chosen as research site. Based on the recommendation of citizens association and integrated coaching services chair, it was chosen as research site that is 09 and 11 citizens association for Bubulak Village, 03 citizens association for Menteng, 04 and 05 citizens association for West Cilendek Village with the consideration of the average of the highest number of elderly.

The type of data used in this study is primary data and secondary data. Primary data obtained by way of direct interview method by using research instrument in the form of structured questionnaire asked by respondent. Primary data from the research questionnaire include: (1) sample characteristics, (2) characteristics of the son-in-law, (3) elderly communication, (4) communication of the elderly, (5) social support, (6) elderly communication and child-elderly communication using the instrument The Revised Family Communication Pattern Instrument was adopted by Ritchie and Fitzpatrick (1990) with a total of 30 statements consisting of 15 statements of socially oriented communication dimensions and 15 concepts of concept-oriented communication dimensions. Each uses a likert scale of $0-3$ ( $0=$ never; $1=$ sometimes; $2=$ often; $3=$ always $)$ with Cronbach alpha 0.653 and 0.927 . Social support was measured by the instruments from Sarason, Levine, Basham et al. (1983) entitled Social Support Questionnaire consists of 10 statements, using likert scale $1-4(1=$ very untrue; $2=$ incorrect; $3=$ true; $4=$ very true) with Cronbach alpha 0.901 . The success of elderly life is measured using instruments from Reker (2009) entitled The Successful Aging Scale consists of 12 statements, using the likert scale $1-5(1=$ strongly disagree; $2=$ disagree; $3=$ neutral; $4=$ agree; $5=$ very agree) with Cronbach alpha 0.884 .

\section{RESULT \\ Characteristics of The Elderly, Children and Son-in-Law}

The elderly in the study was 60 to 69 years old and had children and a sonin-law. Table 1 shows that the mean age of the elderly is 64.0 years slightly higher than the age of the elderly 63.6 years. In addition to the length of education, the average length of education elderly men 8.80 years older than the elderly women 6.17 years. The average large family of elderly women (7 people) is greater than the elderly men ( 6 people). The result of t-test shows that there is difference of education between men and women elderly. The majority of elderly women $(83.3 \%)$ and elderly men $(70.0 \%)$ are not working. The number of elderly women does not work higher than the number of elderly men who are not working. The average age of children and age of men in the elderly men is higher than the elderly women. Hightest age of children in elderly women is higher than the highest age of children in elderly men, but at the maximum age of the son in the elderly men is higher than the maximum age of the daughter in law. The result of t-test shows that there is no difference of age of child and age of law in elderly man and woman elderly. Most of the number of children in elderly men is female, since in elderly women have the same proportion in boys and girls. More than half the number of daughters in the elderly male and female male. 


\section{Elderly-Child Communication and Elderly-Child in Law Communication}

The average social oriented communication score of elderly and children at elderly men is higher than that of elderly women in terms of expecting their children to always obey orders and feel annoyed if they have differences of opinion with children, since more elderly women feel not awkward to tell many things with children. The results of the t-test show that there is a difference between elderly men and women in terms of discussions about health with children and the elderly understanding of adult children to make choices for themselves. Based on the distribution of answers, elderly men tend to assume that it is important to have power at home, while elderly women are more accustomed to giving advice to children and assume that children hope to be involved in making rules at home.

The average score of elderly-child oriented to communication concept on elderly women is higher than the elderly men in the case of more frequent requests for children to take out treatment and tell the problems that occur both with spouses and with peers. In addition, elderly women also have higher mean scores on some other statements such as giving ideas, confidence, and motivation to children in the face of problems, while the elderly men have a higher average value on the statement "Never heard if give ideas or suggestions". The results of t-test show that there is a difference between elderly men and women in terms of talking about activities that have been done everyday.

The results of the analysis based on the elderly-child communication dimension show that the mean index of social elderly-oriented and concept-oriented dimensions of communication in elderly women is higher than the elderly men. The result of t-test shows no difference in social oriented communication dimension and concept-oriented communication between elderly men and women.

Table 1 shows that more than two-thirds of the elderly men $(70.0 \%)$ and most elderly women $(83.3 \%)$ in elderly communication with children were in the moderate category, the rest being in the low category. The average index of elderly communication with children in elderly women is higher than the average male elderly. However, t-test results show no difference in communication with children in elderly men and elderly women.

The average communication scores of elderly men-oriented social elderly men is higher than the elderly women in assuming that the son-in-law should not argue with older people. Elderly women have a higher average value than the elderly men in terms of providing advice to the daughter-in-law and agreed in discussing health problems. T-Test results show that there is a difference between the elderly men and women in the sense that the son-in-law does not argue with the elderly and the assumption that the son-in-law should not argue with parents about anything. Based on the distribution of answers, elderly men tend not to feel awkward to tell a lot of things with the daughter-in-law, since the elderly women tend to assume that his son-in-law hopes to be involved in determining the rules or decisions at home.

The communication of elderly and child was oriented to the concept of elderly men who tend to talk more often about planning and hope for the future of the sonin-law, taking the time to go with children, daughters and grandchildren and more often tell the problems that occur both with couples and with peers. Elderly women have a higher average value than the elderly men in talking about daily activities. 
T-Test results show that there is a difference between elderly men and women in terms of providing ideas, beliefs and motivations as well as support for expressing feelings.

The average index of social-oriented and concept-oriented elderly communication dimensions in elderly men is higher than in elderly women. However, t-Test results show no difference in the dimensions of social communication oriented or concept-oriented communication between elderly men and women. The average index of male elderly communication dimensions with children is socially oriented and concept-oriented is higher than that of a son-inlaw. However, t-test results show no differences in the dimensions of social communication oriented and concept-oriented communication between children and children. While the average index of women's elderly communication dimensions with children oriented social and concept-oriented higher than the sonin-law. However, t-test results show no differences in the dimensions of social communication oriented and concept-oriented communication between children and children.

Table 1 shows that as many as two-thirds of the elderly men in elderly communication with the son-in-law are in the moderate category, the rest are in the low category. While the elderly female communication with the daughter-in-law has the same amount in the low and medium group as much as 50 percent. The result of t-test shows that there is no difference between elderly men and elderly women in elderly communication with son-in-law.

Table 1 Distribution of elderly based on elderly communication with child and child in law and gender

\begin{tabular}{|c|c|c|c|c|}
\hline \multirow{2}{*}{ Group of Elderly-Child Communication } & \multicolumn{2}{|c|}{ Elderly Men } & \multicolumn{2}{|c|}{ Elderly Women } \\
\hline & $\mathrm{n}$ & $\%$ & $\mathrm{n}$ & $\%$ \\
\hline Low $(<60)$ & 8 & 26.7 & 5 & 16.7 \\
\hline Medium (60-80) & 21 & 70.0 & 25 & 83.3 \\
\hline $\operatorname{High}(>80)$ & 1 & 3.3 & 0 & 0.0 \\
\hline Total & 30 & 100.0 & 30 & 100.0 \\
\hline Average & \multicolumn{2}{|c|}{62.148} & \multicolumn{2}{|c|}{64.296} \\
\hline Min-Max & \multirow{2}{*}{\multicolumn{2}{|c|}{$42.2-84.4$}} & \multirow{2}{*}{\multicolumn{2}{|c|}{$52.2-73.3$}} \\
\hline p-value & 0.228 & & & \\
\hline Group of Elderly-Child & \multicolumn{2}{|c|}{ Elderly Men } & \multicolumn{2}{|c|}{ Elderly Women } \\
\hline Communication & $\mathrm{n}$ & $\%$ & $\mathrm{n}$ & $\%$ \\
\hline Low $(<60)$ & 10 & 33.3 & 15 & 50.0 \\
\hline Medium (60-80) & 20 & 66.7 & 15 & 50.0 \\
\hline $\operatorname{High}(>80)$ & 0 & 0.0 & 0 & 0.0 \\
\hline Total & 30 & 100.0 & 30 & 100.0 \\
\hline Average & \multicolumn{2}{|c|}{59.889} & \multicolumn{2}{|c|}{58.815} \\
\hline Min-Max & \multirow{2}{*}{\multicolumn{2}{|c|}{$42.2-80.0$}} & \multicolumn{2}{|c|}{$43.3-70.0$} \\
\hline p-value & & & & \\
\hline
\end{tabular}

\section{Social Support}

The average score of social support in the elderly men is higher than the elderly women in the statement "when eating is always there to go with" and "when sick there is caring". The elderly woman has a higher average grade than the elderly 
men on the statement "when traveling difficulties find someone to go with" and "feel no place to share worries and sadness". T-test results show that there is a difference between the elderly men and women in the presence of someone who can be contacted to fletch the elderly when they are in a place and often elderly are not involved in the family's children and son-in-law.

Table 2 shows that two-thirds of the elderly men and nearly three-quarters of the elderly women in social support are in the moderate category. The average social support of elderly women is higher than the elderly men. The result of t-test shows that there is no difference between elderly men and women elderly in social support.

Table 2 The distribution of elderly's social support based on gender

\begin{tabular}{lcccc}
\hline \multirow{2}{*}{ Group of Social Support } & Elderly Men & \multicolumn{2}{c}{ Elderly Women } \\
\cline { 2 - 5 } & $\mathrm{n}$ & $\%$ & $\mathrm{n}$ & $\%$ \\
\hline Low $(<60)$ & 1 & 3.3 & 0 & 0.0 \\
Medium (60-80) & 20 & 66.7 & 22 & 73.3 \\
High $(>80)$ & 9 & 30.0 & 8 & 26.7 \\
\hline Total & 30 & 100.0 & 30 & 100.0 \\
\hline Average & \multicolumn{2}{c}{76.778} & \multicolumn{2}{c}{67.889} \\
Min-Max & $56.7-96.7$ & \multicolumn{3}{c}{$0.662-100.0$} \\
p-value & \multicolumn{4}{c}{} \\
\hline
\end{tabular}

\section{Succesful Aging}

The average success score of elderly life in elderly men is higher than the elderly women in the statement "feel healthy" and "happy, independent, and successful in life". Elderly women have a high average score compared to elderly men in the statement "not easy to panic when they have problems", "open and trust each other" and "active in activities in the community". The results of t-test show that there is difference between elderly men and women in terms of avoiding things that can damage health and feel unable to blend and not accepted by the environment. Based on the distribution of answers, elderly women tend to feel more unable to solve problems without the help of others, but more trying to have a healthier lifestyle than the elderly men.

Table 3 shows that almost three quarters of the elderly men and most of the elderly women are in the middle category, the rest are in the high category of succesful aging. The average success of women's elderly life is higher than the elderly men. The results of t-Test showed that there is no difference in the success of life in elderly men and women elderly.

Table 3 The distribution of elderly based on the elderly's successful life and gender

\begin{tabular}{lcccc}
\hline \multirow{2}{*}{ Group of Elderly's Successful Life } & \multicolumn{2}{c}{ Elderly } & \multicolumn{2}{c}{ Elderly Women } \\
\cline { 2 - 5 } & $\mathrm{n}$ & $\%$ & $\mathrm{n}$ & $\%$ \\
\hline Low $(<60)$ & 1 & 3.3 & 0 & 0.0 \\
Medium $(60-80)$ & 22 & 73.3 & 24 & 80.0 \\
High $(>80)$ & 7 & 23.3 & 6 & 20.0 \\
\hline Total & 30 & 100.0 & 30 & 100.0 \\
\hline Average & \multicolumn{2}{c}{74.722} & 77.431 \\
Min-Max & $58.3-89.6$ & \multicolumn{3}{c}{$64.4-95.8$} \\
p-value & \multicolumn{4}{c}{0.152} \\
\hline
\end{tabular}




\section{Relationship between Variables}

Table 4 show that no significant relationship between elderly characteristics with the others. However there is a very significant positive relationship between elderly-child communication variables with communication elderly-child in law and social support. Positive relationship is very significant there is also on the communication of elderly-in-law with social support. The higher of elderly-child communication and the elderly-in-law communication will increase social support. In addition, there is a significant positive relationship $(\mathrm{p}<0.05)$ between social support and the success of elderly life. This means that the higher the social support, the higher the success of elderly life.

Table 4 Relationship of elderly characteristics, elderly-child communication, elderly-child in law communication and social support with the elderly's life successful

\begin{tabular}{|c|c|c|c|c|}
\hline $\begin{array}{r}\text { Relationship } \\
\text { variables }\end{array}$ & $\begin{array}{l}\text { Communicatio } \\
\mathrm{n} \text { elderly with } \\
\text { children }\end{array}$ & $\begin{array}{l}\text { Communicatio } \\
\mathrm{n} \text { elderly with } \\
\text { children-in- } \\
\text { law }\end{array}$ & Support social & $\begin{array}{l}\text { Elderly Life } \\
\text { Successful }\end{array}$ \\
\hline Age (years) & -0.050 & 0.069 & 0.053 & -0.126 \\
\hline $\begin{array}{l}\text { Gender }(1=\text { male, } 2= \\
\text { female })\end{array}$ & 0.158 & -0.064 & 0.058 & 0.187 \\
\hline Family size (people) & 0.170 & 0.060 & 0.194 & -0.094 \\
\hline $\begin{array}{l}\text { Lenght of education } \\
\text { (years) }\end{array}$ & -0.178 & -0.162 & -0.091 & -0.039 \\
\hline $\begin{array}{l}\text { Working status }(1= \\
\text { work, = not working })\end{array}$ & 0.133 & -0.184 & -0.003 & 0.031 \\
\hline $\begin{array}{l}\text { Communication elderly } \\
\text { with children }\end{array}$ & 1 & $0.522 * *$ & $0.441 * *$ & 0.189 \\
\hline $\begin{array}{l}\text { Communication elderly } \\
\text { with children in law }\end{array}$ & & 1 & $0.347 * *$ & 0.131 \\
\hline Social support & & & 1 & $0.265 *$ \\
\hline Elderly life succesful & & & & 1 \\
\hline
\end{tabular}

Description : *=significant at $\mathrm{p}<0.05 ; * *=$ significant at $\mathrm{p}<0.01$

\section{Influence of Elderly Characteristics, Elderly Communications, Elderly Communication, and Social Support for Elderly Success}

Table 5 shows the value of adjusted $\mathrm{R}^{2}$ in the success dimension life of 0.086 . This means that the success of elderly life is influenced by factors about 8.6 percent and 91.4 percent explained by other variables outside the variables studied. The result of regression test shows that there is a significant positive effect on social support variable to the success of elderly life $(p<0.05)$, it means that every increase of one social support unit will increase the successful of the elderly by 0.177 points. This result is obtained from backward method by using model 6 from 8 existing model. Elderly-child and elderly-child in law communications have been eliminated on model 6 and the remaining characteristics of gender and large families of elderly, as well as social support variables that affect the success of elderly life, but only social support variables that have a significant effect. 
Table 5 The Influence of elderly characteristics, elderly-child communication, elderly-child in law communication and social support on the life successful of elderly

\begin{tabular}{lccc}
\hline \multirow{2}{*}{ Variable } & \multicolumn{3}{c}{ The life successful of elderly } \\
\cline { 2 - 4 } & B unstandardized & B standardized & Sig. \\
\hline Constant & 59.408 & & 0.000 \\
Gender $(0=$ male, $1=$ female $)$ & 2.936 & 0.203 & 0.114 \\
Family size (person) & -0.704 & -0.186 & 0.154 \\
Social support & 0.217 & 0.290 & $\mathbf{0 . 0 2 6}$ \\
\hline $\mathrm{R}^{2}$ & & 0.132 & \\
Adjusted $\mathrm{R}^{2}$ & & 0.086 & \\
$\mathrm{~F}$ & & 2.849 & \\
\hline
\end{tabular}

Description : *=significant $\mathrm{p}<0.05$

\section{DISCUSSION}

Almost all elderly have moderate group in communicating with child. Age of children who have grown up and generally have married to make communication between parents and children less and less. Communication elderly women with children is higher due to more frequent discussions about health problems and more often ask each other news and more often talk about many things such as daily activities. This is in according with Indriyati (2007) study which states that the relationship between mother and child is closer than father and child, and communication with mother covers everyday problems.

Communication elderly men with a daughter-in-law higher than the elderly women. In elderly men the number of men-in-law more than the daughter-in-law. In social-oriented dimensions communication and the concept of elderly men with daughter-in-law also show higher results, this means older men are better able to maintain communication, avoid arguments, and develop an assessment of a problem with a son-in-law. This is probably due to the gender equation between the elderly men and the men-men. Interact daily of elderly with child and child in-laws will require interpersonal communication skills as they can create openness and reach mutual agreement so as to establish a harmonious relationship (Oktovanni 2010). Openness in communication-in-law with child-in-law can improve relationships with each other because both parties can understand each other (Kuantaraf 1999).

Things that may lead to lower elderly communication with the son-in-law that is like age differences, different places to live, lack of openness and time to meet and talk. According to Purnamasari and Rahmatika (2016), the low-level of elderly woman communication with the children in-law due to the working conditions that make the intensity of meeting with mother-in-law to be reduced.

The results showed that the largest proportion of elderly men and women elderly in social support is in the medium category, this is because there are still elderly who find it difficult when traveling because no one go with and feel that the child or son-in-law does not understand the things he wants or likes objects or favorite foods. Cobb (1976) in Sarafino (1997) states that social support is defined as a comfort, attention, appreciation, or the perceived help of the person from 
others. The average social support of elderly women is higher than the elderly men. According to Potter and Perry (2006) when viewed from the sexes, women pay more attention to the problems so that advice and response from others, especially families is needed, while men are very rare to ask for help (Papalia 2009). Social support will be more meaningful to a person if given by people who have significant relationships with the individual concerned, such as parents, spouses, children and relatives (Taylor 1995). This is in line with Rodin and Salovey in Smet (1994) which show that the most important social support is that of the family.

In the life success variable of almost three-quarters of the elderly men and most elderly women are in the medium category. Rowe and Khan (1997) describe successful aging as the ability to manage three key characteristics or behaviors. The first is to reduce the risk of various diseases and consequences associated with the disease, the second is to manage both physical and psychological functions, and the third is the active involvement with life. The results show that there is no difference between elderly men and elderly women in the success of elderly life. This is not according with the research of Setiyartomo (2004) who found there are differences of successful aging in terms of gender, this is because elderly men are more able to make adjustments to the loss of spouses than the elderly women.

The correlation test results show that the elderly-child communication has a very significant positive relationship with the elderly-child in law communication, it means the better the elderly-child communication then the better the communication of the elderly-in-law. Aryani and Setiawan (2007) mentioned that there are several relationships that occur between the law-in-law and the in-laws, namely conflict-filled, indifferent, and harmonious. Factors that can affect the relationship of in-laws and in-laws are the personality and the age difference that is far enough and the role of the child needed as an intermediary in an effort to improve relationships. Elderly-child communication and elderly communication have a very significant positive relationship with social support. This means that the higher the elderly communication with the child and the son-in-law will increase social support. This research is in line with Muladsih (2011) which states that communication patterns have a positive and tangible relationship with social support. Social support also has a significant positive relationship with the success of life, meaning that the higher the social support will be the higher the success of elderly life. In line with research Budiarti (2010) which states that social support primarily from the family is a factor from outside the individual self needed to achieve successful aging. Regression test results show that there is a significant positive effect on social support to the success of elderly life. Azizah (2011) stated that family support can decrease the tendency of the emergence of causes of stress. Positive support from spouses, children, family and friends significantly reduces the ill effects of stress, otherwise negative support will increase the effects of adverse stress. Minimizing negative support and maximizing positive support will lead to elderly success (Ahn et al., 2016).

\section{Conclusion}

\section{CONCLUSION AND SUGGESTION}

The average age and duration of elderly men's education is higher than the elderly women. Most elderly men and women do not work. Elderly-child 
communication, elderly-child in law communication, social support and successful life of elderly men and women are in the medium category. In social-oriented elderly-oriented communication and concepts in the elderly men and women have similarities in terms of talking about daily activities and planning and hope for life in the future. In elderly social-oriented communication and concepts in the elderly men and women have similarities in terms of discussions about health problems. Social support that equally needed elderly men and women is the presence of someone who can care for the elderly when sick and accompany when traveling. The success of life felt by elderly men and women elderly have similarities, but for elderly men tend to be more trying to be independent in solving problems, while the elderly women are more trying to have a healthy lifestyle. Elderly-child communication and elderly communication have a very significant positive relationship with social support. Social support is related and has a significant positive effect on the success of elderly life. The higher the social support the higher the success of elderly life.

\section{Suggestion}

Based on the results of the study is expected elderly to improve communication with family members because of the openness in communication can increase social support. Elderly can share the problems experienced by family members and give trust to family members to try to solve the problem, in which case the elderly must also be able to accept or consider the opinions and suggestions of others, some of which may improve the pattern of elderly communication with family. Children, in-laws and other family members should seek more information about what parents need when they are older. Social support can also be achieved through involvement in community activities and programs organized by integrated counseling services or elderly family coaching. In addition, the elderly should be able to live independently and reduce dependence on others. For further research, the need for two-way research considering this study only based on the point of view of elderly only, as well as the existence of research that distinguishes elderly communication with children or men and women's in-law.

Limitations of this study that is, research only focus on the point of view of the elderly, preferably in later research children's perceptions and son-in-law are also investigated. In addition, this study was conducted in one particular area, so the results of this study can not be generalized in many regions

\section{REFERENCES}

The difference of successful aging in the elderly is viewed from the gender [Underthesis]. Semarang (ID): State University of Semarang.

Ahn, S.N., Kim, S.H., Zhang, H. (2016). Changes in depressive symptoms among older adults with multiple chronic conditions: Role of positive and negative social support. J of Enviromental Research and Public Healt.

Aryani, D.R., Setiawan, J.L. (2007). Pattern of interpersonal conflict relation between daughter-in-law and mother-in-law. Journal of Psychology.12(2): 77-90.

Azizah. (2011). Elderly nursing.. Yogyakarta (ID):Graha Ilmu. 
Budiarti. (2010). Factors successful aging. [Underthesis]. Malang (ID): University of Muhammadiyah Malang.

[CBS] Central Bureau of Statistic. (2010). Data of the Elderly Population. Jakarta (ID): CBS.

Bogor City Central Bureau of Statistics. (2015). People aged 15 years and over who work by age group. Jakarta (ID): CBS.

. Bogor City Central Bureau of Statistics. (2016). Number of elderly population. Jakarta (ID): CBS.

Indriyati. (2007). The relationship between parents' communication with selfesteem of early adolescence [Underthesis]. Semarang (ID): State University of Semarang.

Kuantaraf, K.H.L. (1999). Family communication. Bandung (ID): Indonesia Publishing House.

Muladsih, O.R. (2011). Communication patterns, decision making, and long-term family welfare in IPB graduate students. Journal of Family and Consumer Science.

Oktovanni, P. (2010). Interpersonal communication barriers between parent in-laws and children in-laws who live in one house [Underthesis]. Surabaya (ID): Petra Christian University.

Olson, D.H., Barnes, H. (2004). Family Communication. Minneapolis (US): Life Innovations, Inc.

Papalia, D.E., Old, S.W., Feldman, R.D. (2009). Human Development. 10th Edition. Jakarta (ID): Kencana.

Perry, Potter. (2006). Nursing Fundamentals of Nursing: Concepts, Processes, Practice. Volume 2. Ed 4th. Jakarta (ID): EGC Medical Book.

Purnamasari, R.P., Rahmatika, R. (2016). Differences in social support from mother-in-law in nursing mothers who work and do not work. Journal of Psychology. 15(1): 21-35.

Prentice. (2008). Communicating with in-laws: Reframing and accepting Chances. A Publication of the National Communication Association.1(1).

Reker, G.T. (2009). Personal meaning orientations and psychosocial adaptation in the later years. Unpublished manuscript, Trent University, Peterborough, ON, Canada.

Ritchie, Fitzpatrick. (1990). Family communication patterns: Measuring Interpersonal perceptions of interpersonal relationship.

Rowe, J.W., Kahn, R.L. (1997). Successful Aging. J Gerontological Society of America. 37(04): 433-440.

Sarafino, E.P. (1997). Health Psychology :Biopsychosocial Interaction. $4^{\text {th }}$ Ed. United States of America: John Wiley \& Sons. . (2006). Health Psychology :Biopsychosocial Interaction. $5^{\text {th }}$ Ed. United States of America: John Wiley \& Sons.

Sarason, I.G., Levine, H.M., Basham, R.B., Sarason, B.R. (1983). Assessing social support: The Social Support Questionnaire. J of Personality and Social Psychology. 44:127-139.

Setiyartomo, P.W. (2004). Successful aging in terms of meaningfulness of life and religious orientation in the elderly [Underthesis]. Yogyakarta (ID): Universitas Gajah Mada. 
Smet, B. (1994). Health Psychology. Jakarta (ID): PT. Grasindo.

Taylor, S.E. (1995). Health Psychology. $3^{\text {th }}$ Ed. United States of America: Mc Graw-Hill Companies. 